\title{
Radosław MARZĘCKI
}

Pedagogical University of Cracow

\section{Young Poles: Undeveloped Political 'Niche'}

\begin{abstract}
Observation of the political life in contemporary Poland leads to the conclusion that young people and their problems remain on the sidelines of communication and the decision-making processes that are initiated by the leading political parties. Young citizens are rarely the addressees of political offers, and their problems, interests, and aspirations rarely become the pivot of political disputes or the content of political discourse. Young citizens perceive the general lack of interest in their matters and point to it as one of the most important criticisms of the political class in Poland. In the article, the author presents the results of a national survey conducted among Polish students in the first half of 2012. They clearly demonstrate that the younger generation still constitutes a vast and underdeveloped political 'niche'.
\end{abstract}

Key words: participation, young people, political apathy, political alienation, young voters

\section{Introduction}

$\mathbf{T}$ he quality of future democracy is difficult to predict today. This is not to say, though, that it is impossible to plan. If we make an assumption that it will depend on the actions undertaken by citizens who are currently gaining political experience, the 'here and now' moment of today becomes crucial, as we all have the greatest impact on it. It is important that those in influential social positions who shape civic behavioural patterns are well aware of this. A young citizen, upon reaching voting age, is bestowed with the right to choose. From a formal point of view, newly come of age citizens become entitled to vote, and at the same time have the chance to exert actual influence on the shape and direction of state politics, the right to give or withdraw their approval of the ruling party, and finally the right to publicly bring forward some of the problems that impact their core interests (Schumpeter, 1995, p. 340). However, this vision of a hypercitizen, one who holds an opinion on all those significant matters that are crucial for the life of their political community, is unquestionably overly idealistic today (Sartori, 2007, p. 94). Coming of political age, each citizen can also exercise their right to remain passive and focus on the private spheres of life. Being active and well-informed is not and should not be treated as an imperative.

\section{Apathetic or Alienated?}

It goes without saying that human behaviour is never fully determined. Crozier and Friedberg believe that even passivity is always a behavioural choice of sorts (Crozier, 
Friedberg, 1982, pp. 57-58). Sometimes, passivity is only seemingly the result of a freely taken decision, though. As part of the negativist discourse, a young man is perceived as the chief 'culprit' to be blamed for non-civic behaviour in the public sphere. However, the lack of interest in undertaking political activity, especially habitual in the younger generation, might prompt one to pose the following question: to what extent is that peculiar pattern of behaviour an expression of internally motivated apathy, and to what extent is it a manifestation of externally forced alienation? The answer to the question is ambivalent, which in itself serves as a suggestion that young people do not necessarily take full responsibility for their level of involvement in public affairs. Our social and political attitudes are essentially elements of a given political culture. Culture, understood as a set of standards, principles, values, and behavioural patterns, always determines the limits of human activity. It maps out the norms which guide us on how to behave, and how not to behave, what pays and brings profit and what does not and is not worth doing, what is socially appreciated, and what will be stigmatised. Thus understood, culture is predefined right from the very beginning of our lives. Even the phenomenon referred to as the "decline of social capital" by Robert Putnam (2001) is rooted in culture. ${ }^{1}$ In light of this, the choices made by young people are somewhat easier to understand.

\section{Socialised to be Marginalised}

When passing judgements on the contribution of young people to the functioning of a political system, it is worth realising that participation, or lack thereof, is not conditioned unilaterally, nor can it be. Sources of passivity and absence can be found both on the side of the young generation, as well as the actual political system (or politicians) in question. Steven Rosenstone and John Hansen explain the dualism in more metaphorical terms: "citizens participate in elections and government both because they go to politics and because politics comes to them" (Rosenstone, Hansen, 1993, p. 6). Among the causes behind civic involvement, or lack thereof, they list the costs (incurred by individuals) and resources (possessed by individuals), on the one hand, and individual interests, preferences, identifications and convictions, on the other. Thus, one can conclude that the more rewards flow in the citizens' direction (from the external world of politics), and the more often and more intensively they are internally motivated to act, the more inclined they are to participate in political life. Rewards and positive reinforcement play the greatest part in the early stages of life, when people acquire particular patterns or habits of political activity or passivity which determine their attitudes over the later periods of life (Kovacheva, 2005, p. 22; see also: Mannheim, 1952). This is why the 'first impression effect' (pertaining to one's first experience with the political system) is so important and determines the political socialisation directions of the young citizens of any democratic state. Eric Plutzer also pays attention to that key moment in life. He emphasises the special importance of the high cost related to one's

\footnotetext{
${ }^{1}$ Forced by the change of people's lifestyle.
} 
decision to participate in the voting process - one which is greater when one lacks the necessary experience. This aspect is also stressed by Mikołaj Cześnik, when he writes that "the great majority of young people enter the electoral arena as potential non-voters. At their age the voting costs are high, because they are doing it for the first time in their life (they do not know where to vote, how to vote, their political knowledge is scarce, etc.)" (Cześnik, 2007, p. 170). Plutzer also claims that young citizens are not well informed about politics, they do not understand the differences between political parties or some of the key political issues, and "their peer group consists almost entirely of other non-voters: their friends cannot assure them that voting has been easy, enjoyable, or satisfying" (Plutzer, 2002, p. 42). The youngest voters, who have never voted before, have numerous reasons not to feel satisfied with their first ever electoral experience which can in turn influence their later attitudes as voting (or non-voting) citizens.

Observation (also academic) of the political life in contemporary Poland leads one to conclude that young people, and their problems, remain on the sidelines of communication and the decision-making processes that are initiated by the leading political parties. The observation is true both for the objective (the actual offers addressed to young people), as well as the subjective (the feeling of 'being taken into consideration') state of play. Young citizens rarely are the addressees of political offers, and their problems, interests, and aspirations rarely become the pivot of political disputes or the content of political discourse. Terry Barber notices the same problem, pondering over the methods of promoting active citizenship among young people in the new Europe. He states that "young people in the main have not been encouraged to get involved in adult decision making because of their perceived lack of maturity" (Barber, 2009, p. 125). Young citizens perceive the general lack of interest in their matters and point to it as one of the most important criticisms of the political class in Poland.

Different social institutions, such as the family, school, or the political system, play a crucial part in the process of shaping and reproducing social life, creating habits, including those in the political sphere. It appears that an important part of the "significant others" (Berger, Luckmann, 1983, pp. 202-249), of the symbolic elite, or opinion-forming individuals, should be played by politicians. This is especially true for young democratic states (Antoszewski, 2000; Marzęcki, 2013, pp. 9-12). Politicians are the ones held accountable for bringing politics closer to citizens. Joerg Forbrig stresses the fact that involvement requires both participation (an internal motive), as well as constant accessibility on the part of political institutions (an external motive) which in turn can bring about a sense of effectiveness (Forbrig, 2005, p. 8). That feeling of effectiveness is indeed one of the main factors stimulating young people's political activity (Dermody, Hanmer-Lloyd, 2008, p. 176). Meanwhile, the experience of social life makes us realise two fundamental barriers for participation. First of all, politicians have lost credibility in the eyes of the young generation, and thus symbolise a sphere of life that is not attractive enough for young citizens. Secondly, politicians themselves dishearten and discourage young people by presenting weak political offers for youth groups, even passing over their problems and interests (see Table 1). 
Opinions on the causes behind voter abstention among young people

\begin{tabular}{||l|c||}
\hline Why do you think young people, more often than other age groups, fail to participate in elections? \\
\hline They are not interested in politics & $26 \%$ \\
\hline They do not feel they have any impact on national matters & $22 \%$ \\
\hline There is no-one to vote for (lack of adequate candidates) & $21 \%$ \\
\hline No political party represents their interests & $21 \%$ \\
\hline They believe voting is out of fashion & $1 \%$ \\
\hline Hard to say & $9 \%$ \\
\hline
\end{tabular}

Source: Author's own study.

Hence, it is so important to pose questions on the moral and intellectual role of the political elite in a democratic society. To what extent do politicians carry out their responsibility to shape the habits of civic activity? How do they distribute their priorities in a democratic system which is a 'competitive fight for electors' votes': is social support an instrument for the achievement of their political and electoral goals, or is it the 'fuel' that feeds the political system and helps implement particular ideas, programmes, solve problems, etc.? Some more questions worth asking involve the following: how do young citizens perceive their role in modern democracies? What is most important for them in politics? What are their problems? Who can be held accountable for them? Who has the best solution for these problems? Do political parties represent young people's interests? What should change in order for young people to be more motivated to get involved in politics? The answers to these questions will be presented further on in the article. ${ }^{2}$ They clearly demonstrate that the younger generation still constitutes a vast and underdeveloped 'niche', not to be solely understood as a potential electorate.

\section{Untapped Potential of the Young Generation}

Seen from a different perspective, the young generation constitutes the enormous quantitative and qualitative potential of Polish society. The youngest citizens, and their political involvement, are gaining in importance today (Forbrig, 2005, p. 13). The fact that in 2008 the 18-24 age group of the European population comprised 44,280,042 citizens, i.e. $8.9 \%$ of all those entitled to vote in the 27 EU Member States, testifies to the significant part they play in the world of today. In Poland, the share of that group is even greater. In 2010, people aged 18-24 constituted $12.6 \%$ of the population with active voting rights. It is worth realising the potential of that group's impact on politics. Today the group comprises ca. 3.8 million voters. To put things in perspective, the winning Civic Platform (PO) party received 5,629,773 votes in the 2011 parliamentary elections, followed by the Law and Justice party (PiS) with as many as 4,295,016 votes. If all eligible

\footnotetext{
${ }^{2}$ Based on the results of a national survey conducted in the first half of 2012. The study sample involved 994 full-time public university students. See also: R. Marzęcki, Ł. Stach, 2013.
} 
young voters had gone to the polls, they would have constituted nearly $40 \%$ of those who voted for the two biggest political groupings.

Table 2

Share of the 18-24 age group in the Polish population and in the population entitled to vote respectively

\begin{tabular}{|c|c|c|}
\hline Year & Polish population & $\begin{array}{c}\text { Population entitled } \\
\text { to vote }\end{array}$ \\
\hline 2007 & $11.3 \%$ & $14.1 \%$ \\
\hline 2010 & $10.2 \%$ & $12.6 \%$ \\
\hline 2030 & $7.5 \%$ & $9.1 \%$ \\
\hline
\end{tabular}

Source: Central Statistical Office, http://www.gus.gov.pl.

Secondly, young people's potential is frequently described in terms of qualitative possibilities. Krystyna Szafraniec is the only one to write about this innovative and civic potential in her report entitled Youth 2011. It is hard to disagree with the observation that young people have more energy, are more open and critical towards the world, express more far-reaching life goals (Szafraniec, 2011, p. 21), and have "numerous other assets (personality-related), which might indicate significant potential for change," including: aspirations to live a better life in a well-functioning society, confidence in their own capabilities and an action style which involves relying on oneself and not paying attention to what other people do (Szafraniec, 2011, p. 34). Unfortunately, one's conviction of the above mentioned potential is poorly reflected in public debate, political discussions or decision-making processes. Politicians themselves frequently admit to it, like for instance Michał Boni, ${ }^{3}$ who is of the opinion that today it is difficult for the ruling generation, formed in the times of the Solidarity mission, to define the role of their historical successors, and to create the conditions for intergenerational solidarity (Szafraniec, 2011, p. 7).

\section{Problems of the Young Generation and Their Political Representation}

Looking into the motivations behind voting declared by young citizens one reaches a very interesting conclusion. It turns out that what is often believed to be the main cause behind voting for a particular political party is only secondary and recedes into the background in real life. It is not the particular world view that is most important for young people, but instead they are much more interested in social matters, such as health care, education, transportation or culture, and first and foremost they focus on economic matters - the greatest source of their day-to-day problems. In light of these findings, the current political offer addressed to young people looks even feebler. The answers to the open question of "what, in your opinion, is the greatest problem facing young people?" involved mainly (over $90 \%$ of them) lack of certainty and security in the labour market and

\footnotetext{
${ }^{3}$ Presently, Minister of Administration and Digitisation in Donald Tusk's government.
} 
in the economic sphere, e.g. no work for the well-educated, unemployment, difficulty purchasing an apartment, no prospects for the future. Young people themselves assess their situation (current or potential) on the labour market in highly critical terms. $93 \%$ of them consider the situation as "poor" or "quite poor", with only $1 \%$ of the group believing their situation to be "good" or "quite good". On the other hand, young people are least interested in the political and historical issues that constitute the chief content of political discourse in modern Poland (Table 3).

Table 3

Priority issues for Polish youth

\begin{tabular}{||l|c||}
\hline $\begin{array}{c}\text { Which of the following issues do you believe are the most important for young people? } \\
\text { Please, arrange them on a scale of 1 (most important) to 5 (least important) }\end{array}$ & Average \\
\hline Economic issues (unemployment, employment, salary, taxes, etc.) & 1.73 \\
\hline Social issues (health care, education, transportation, culture, etc.) & 2.41 \\
\hline World views (state-church relationship, abortion, civil unions, legalisation of drugs, etc.) & 2.47 \\
\hline Political issues (vision of state, financing of political parties, foreign policy, etc.) & 3.72 \\
\hline Historical issues (assessment of the past, historical policy, etc.) & 4.39 \\
\hline
\end{tabular}

Source: Author's own study.

The set of problems presented above is closely linked with the list of entities that young people blame the current situation on. They point to politicians in the first place, and to the educational system (whose quality is also impacted by politicians) secondly. Self-criticism is much less common (Table 4).

Table 4

Opinions on who bears responsibility for unemployment among young people

\begin{tabular}{|l|r|}
\hline \multicolumn{2}{|c|}{$\begin{array}{c}\text { Who, in your opinion, is responsible for the unemployment } \\
\text { among young people? }\end{array}$} \\
\hline Politicians & $39.5 \%$ \\
\hline Educational system & $32.2 \%$ \\
\hline Young people themselves & $4.1 \%$ \\
\hline Parents & $0.5 \%$ \\
\hline Hard to say & $23.8 \%$ \\
\hline
\end{tabular}

Source: Author's own study.

The political elite is generally assessed very harshly. In fact, none of the political parties are perceived as a player who has a good idea and sufficient capacity for the implementation of a programme which would counteract the effects of the economic crisis. Even though the hopes of young people reflect their political sympathies (greatest towards PO and PiS), still over $62 \%$ of respondents complain that no-one on the political scene has a good solution for the country's economic problems. 
Table 5

Opinions on party ideas for combating the economic crisis

\begin{tabular}{|c|c|}
\hline \multicolumn{2}{|c|}{$\begin{array}{l}\text { Which of the political parties has the best solution } \\
\text { for the economic crisis? }\end{array}$} \\
\hline Congress of the New Right (KNP) & $5.4 \%$ \\
\hline Civic Platform (PO) & $11.9 \%$ \\
\hline Poland Comes First (PJN) & $1.6 \%$ \\
\hline Polish Labour Party (PPP) & $0.7 \%$ \\
\hline Polish People's Party (PSL) & $1.2 \%$ \\
\hline Law and Justice (PiS) & $7.6 \%$ \\
\hline Palikot's Movement (RP) & $5.4 \%$ \\
\hline Democratic Left Alliance (SLD) & $2.6 \%$ \\
\hline United Poland (SP) & $0.6 \%$ \\
\hline Other party & $0.6 \%$ \\
\hline Neither & $62.4 \%$ \\
\hline
\end{tabular}

Source: Author's own study.

The aim of the presented set of empirical data is to demonstrate the multifaceted and diverse nature of young people's disappointment with the world of politics. Polish students are convinced that their interests are not represented in public debate, neither by political parties, nor by the broader opinion-forming elites. The mean values calculated on the basis of the 5-point scale presented in Table 6 clearly demonstrate that the only party which is perceived as one that takes young people's interests into account is Ruch Palikota (Palikot's Movement). However, it is still assessed rather negatively, as the score received is only 0.33 higher than the metric centre of the scale, denoting a balance between positive and negative opinions. None of the remaining parties has made it beyond that threshold.

Table 6

Opinions on the representation of young people's interests

\begin{tabular}{|l|c|}
\hline $\begin{array}{c}\text { To what extent do political parties represent young } \\
\text { people's interests? (1 - to the least extent, 5 - to the } \\
\text { greatest extent) }\end{array}$ & Average \\
\hline Congress of the New Right (KNP) & 2.46 \\
\hline Civic Platform (PO) & 2.65 \\
\hline Poland Comes First (PJN) & 2.27 \\
\hline Polish Labour Party (PPP) & 1.99 \\
\hline Polish People's Party (PSL) & 2.07 \\
\hline Law and Justice (PiS) & 2.20 \\
\hline Palikot's Movement (RP) & 3.33 \\
\hline Democratic Left Alliance (SLD) & 2.60 \\
\hline United Poland (SP) & 2.10 \\
\hline
\end{tabular}

Source: Author's own study. 
Young Poles unanimously (80.8\%) express a conviction that their interests are not sufficiently represented as part of the public debate. Only $5 \%$ of them hold a different opinion on the matter. Hence, it is worth asking the following question: whose interests, problems, and opinions are most frequently taken into consideration by politicians during their decision-making processes? Table 7 illustrates young citizens' answers to the question. It would seem that politicians take their own interests into consideration in the first place, as well as those of particular interest groups. The ordinary man (voter or citizen), on the other hand, is pushed on to the sidelines of political activity.

Table 7

Opinions on the addressees of political actions

\begin{tabular}{||l|c|c||}
\hline $\begin{array}{c}\text { Whose interests, problems, and opinions are most frequently taken into } \\
\text { consideration by politicians during their decision-making processes? }\end{array}$ & Yes & No \\
\hline Only their own & $63.7 \%$ & $11.5 \%$ \\
\hline Their voters & $31.2 \%$ & $40.1 \%$ \\
\hline All of the citizens & $11.3 \%$ & $61.6 \%$ \\
\hline Interest groups (e.g. business, professional groups) & $68.9 \%$ & $12.3 \%$ \\
\hline Those of other countries & $33.8 \%$ & $37.1 \%$ \\
\hline Those of the Church & $27.8 \%$ & $41.7 \%$ \\
\hline
\end{tabular}

Source: Author's own study.

In the context of the above data, it should come as no surprise that over two thirds (63.8\%) of respondents would consider voting for a "Youth Party", should one appear on the Polish political arena ready to pay special attention to the problems and interests of the younger generation. Even though nearly one quarter $(24.5 \%)$ hold no opinion on the subject, only one in ten respondents rejects such a possibility altogether. Finally, it is worth looking at young people in terms of 'critical citizens' who can provide support for democracy. In the light of much empirical data and international comparative studies, young people clearly support democracy as a form of rule, but they are dissatisfied with its functioning, which is why they should be perceived not as a threat, but as a driving force behind reforms and enhanced democratic processes and structures (Klingemann, 1999, p. 32). Even though they often express negative and dismissive opinions on politicians and their actions, they can voice rational demands for changes - the essence of which is an improved quality of democracy (Dermody, Hanmer-Lloyd, 2008, p. 176). In their opinion, political parties must be willing to take notice of the problems affecting young people, and politicians need to start taking decisions with a view to solving those problems. This is the attitude represented by the majority of young Poles. Nearly half of them is of the opinion that there should be greater freedom of voting outside of one's place of permanent residence, and roughly a quarter of them believe that citizens should have the right to dismiss a politician they have previously elected, that the promotion of young people within political structures should be made easier (e.g. political parties), and that voters should be able to select the following option: "I choose not to vote for anyone." 
Young people's ideas for changing the current situation

\begin{tabular}{|l|r||}
\hline \hline What do you think would need to change in order for young people to be more motivated to vote? \\
\hline Political parties must be willing to take notice of the problems affecting young people & $59.8 \%$ \\
\hline Politicians need to start taking decisions with a view to solving problems affecting young people & $56.0 \%$ \\
\hline Promotion of young people within political structures should be made easier & $22.9 \%$ \\
\hline Famous people should urge to vote & $5.7 \%$ \\
\hline $\begin{array}{l}\text { There should be greater freedom of voting outside of one's place of permanent residence (e.g. } \\
\text { via Internet) }\end{array}$ & $42.6 \%$ \\
\hline Voters should be able to select the following option: "I choose not to vote for anyone" & $20.3 \%$ \\
\hline Citizens should have the right to dismiss a politician they have previously elected & $26.5 \%$ \\
\hline
\end{tabular}

Source: Author's own study.

\section{Conclusions}

Reflections on the role and position of the young generation in modern democratic Poland leads to several conclusions. First of all, it appears that the young people of today are becoming apolitical, as that sphere of life is simply unappealing to them. Secondly, politicians are perceived, not without reason, as an alienated class of people who take care of their own interests solely, while the style and language of politics, full of hypocrisy and empty clichés, drives ordinary people away, being too aggressive and complicated. Thirdly, the dissociation of young people from politics and politicians leads to a situation where the number of contacts with the world of politics is reduced, this in turn translates into poorer dissemination of information on political matters to the young generation. Finally, the lack of sufficient information leads to poorer knowledge, and consequently poorer political sophistication, followed by lower participation indices. The above presented data reflects, though perhaps indirectly, the urgent need to treat young people in a more individual way. What is also deemed necessary is that politics not be limited to administration only, but for it to be a dialogue, ${ }^{4}$ first and foremost. Public opinion can then constitute a challenge for the political elite, making it impossible to leave important questions unanswered. It requires equipping the society with the right to take concrete decisions, going beyond ritual participation in public elections (Inglehart, 1977, p. 3). Potential means possibilities, frequently unexploited ones, which is why it is worth looking into young people's potential for social involvement, and whether it is likely to be well harnessed in the future.

\section{Literature}

Antoszewski A. (2000), Spoleczeństwo obywatelskie a proces konsolidacji demokracji, in: Studia $z$ teorii polityki, eds. A. Czajowski, L. Sobkowiak, vol. 3, Wydawnictwo Uniwersytetu Wrocławskiego, Wrocław.

${ }^{4}$ An example taken from social life is the anti-ACTA protests. 
Barber T. (2009), Choice, Voice and Engagement: Models and Methods Promoting Active Youth Citizenship in the New Europe, in: Challenges for Citizenship, Citizenship Education and Democratic Practice in Europe, eds. D. Dolejšiová, M. Á. García López, Council of Europe, Strasbourg.

Berger P. L., Luckmann T. (1983), Społeczne tworzenie rzeczywistości, Państwowy Instytut Wydawniczy, Warszawa.

Crozier M., Friedberg E. (1982), Człowiek i system. Ograniczenia działania zbiorowego, PWE, Warszawa.

Cześnik M. (2007), Partycypacja wyborcza w Polsce. Perspektywa porównawcza, Scholar, Warszawa.

Dermody J., Hanmer-Lloyd S. (2008), $21^{\text {st }}$ Century British Youth: Politically Alienated or an Engaged Critical Citizenry?, in: Citizenship in the $21^{\text {st }}$ Century, eds. L. T. Kane, M. R. Poweller, Nova Publishers, New York.

Forbrig J. (2005), Introduction: Democratic Politics, Legitimacy and Youth Participation, in: Revisiting Youth Political Participation: Challenges for Research and Democratic Practice in Europe, ed. J. Forbrig, Council of Europe, Strasbourg.

Inglehart R. (1977), The Silent Revolution: Changing Values and Political Styles Among Western Publics, Princeton University Press, Princeton.

Klingemann H.-D. (1999), Mapping Political Support in the 1990s: A Global Analysis, in: Critical Citizens, Global Support for Democratic Governance, ed. P. Norris, Oxford University Press, Oxford.

Kovacheva S. (2005), Will Youth Rejuvenate the Patterns of Political Participation?, in: Revisiting Youth Political Participation: Challenges for Research and Democratic Practice in Europe, ed. J. Forbrig, Council of Europe, Strasbourg.

Mannheim K. (1952), The Problem of Generations, in: Essays on the Sociology of Knowledge, ed. P. Kecskemeti, Routledge and Kegan Paul, London.

Marzęcki R. (2013), Styl uprawiania polityki. Kształtowanie i utrwalanie podziałów politycznych we współczesnej Polsce, Wydawnictwo Naukowe Uniwersytetu Pedagogicznego, Kraków.

Marzęcki R., Stach Ł. (eds.) (2013), Dlaczego Palikot? Młodzi wyborcy Ruchu Palikota: przypadkowy czy "twardy" elektorat nowej sity na polskiej scenie politycznej, Elipsa, Warszawa.

Plutzer E. (2002), Becoming a Habitual Voter: Inertia, Resources, and Growth in Young Adulthood, "American Political Science Review", vol. 96, no. 1.

Putnam R. D. (2001), Bowling Alone. The Collapse and Revival of American Community, Simon \& Schuster, New York.

Rosenstone S. J., Hansen J. M. (1993), Mobilization, Participation, and Democracy in America, Macmillan, New York.

Sartori G. (2007), Homo videns. Telewizja i postmyślenie, Wydawnictwo Uniwersytetu Warszawskiego, Warszawa.

Schumpeter J. A. (1995), Kapitalizm, socjalizm, demokracja, PWN, Warszawa.

Szafraniec K. (2011), Youth 2011. Poland, The Chancellery of the Prime Minister, Warszawa.

\section{Streszczenie}

\section{Młodzi Polacy: Niezagospodarowana polityczna "nisza"}

Obserwacja życia politycznego we współczesnej Polsce prowadzi do wniosku, że młodzi ludzie, wraz ze swoimi problemami, pozostają na marginesie komunikacji i procesów decyzyjnych inicjowanych przez najważniejsze partie polityczne. Młody człowiek rzadziej bywa adresatem politycznych 
ofert, a problemy, interesy i aspiracje tej grupy ludzi rzadziej stają się osią politycznych sporów i treścią politycznych dyskursów. Młodzi obywatele dostrzegają ten brak wyraźnego zainteresowania ich sprawami i czynią z niego jeden z ważniejszych argumentów krytycznych wobec klasy politycznej. Autor prezentuje w artykule wyniki badania ankietowego zrealizowanego wśród polskich studentów w pierwszej połowie 2012 roku. Wskazują one, że młode pokolenie stanowi wciąż wielką niezagospodarowaną polityczną "niszę".

Słowa kluczowe: partycypacja, młodzież, polityczna apatia, polityczna alienacja, młodzi wyborcy 
